\title{
The Relationship between Humor Styles and Five Factor Personality Traits of Physical Education and Sports Students
}

\author{
Utku Isik ${ }^{1, *}$, Recep Cengiz ${ }^{2}$ \\ ${ }^{1}$ Department of Physical Education and Training, School of Physical Education and Sport, \\ Recep Tayyip Erdogan University, Rize, Turkey \\ ${ }^{2}$ Department of Recreation, Faculty of Sport Science, Manisa Celal Bayar University, Manisa, Turkey
}

Copyright $\mathrm{O} 2018$ by authors, all rights reserved. Authors agree that this article remains permanently open access under the terms of the Creative Commons Attribution License 4.0 International License

\begin{abstract}
The purpose of the study was to investigate the relationship between the humor styles and personality of the students of Physical Education and Sports College. The sample of the study consists of 732 students who have been established by random method and study in four different physical education and sports colleges of Turkey in 2014-2015 the spring term. "The Five Factor Personality Traits" and "Humor Styles Questionnaire" were applied to determine scores of the five factors personality traits and humor styles of students. The findings of this research have been summarized below. No significant difference has been found between average scores of participating students' gender, personality and humor styles. In terms of age variable, the mean neuroticism scores of participants in the age range from 23 and above are significantly higher in comparison to participants in the age range 22 and below. Consequently, it has been determined that there is a relation between the five factor personality traits and students' humor styles, besides it has been raised significant differences on their five factor personality traits and humor styles according to variables of participants' age and class.
\end{abstract}

Keywords University Students, Personality, Humor Styles

\section{Introduction}

Personality, which is as an important decisive of individual behaviors on work and social environments, expresses that a conscious person comprehends itself as a subject unique and ongoing with the most general expression [1]. Personality tests are the basic tools used to measure personality which is total of individual's physiological, mental and spiritual characteristics. For this purpose The five factor model of personality based on "Traits Approach" is accepted and the most commonly used in various personality tests claimed they measure different dimensions" [2]. This approach, which Eysenck leads, has been benefited from "the attributes" that the individuals use to describe themselves and others about measuring the personality and it has been focused on revealing the structures in the lower level by analyzing to these traits with the deduction perspective $[3,4]$. The basis of researches intended the five factor personality traits lies until Jung's Typology that distinguish the personality traits as "introversion" and "extroversion" [3]. According to Typology, It is defined as "introversion" that People who loves loneliness, shies and acts individually and "extroversion" that people who not being alone, spends others time, not being shy [5]. Even though these approaches has different starting points, They have explained two basis structures such as "Extroversion" and "Neuroticism" can be gathered under the five factor personality traits at a lower level. In this personality structure which revealed the personality as The Five factor, Personality is called as Extroversion (energetic, talkative, friendly, exciting, enthusiastic and be social), Neuroticism (depression, irritability, sensitivity, compassion, being anxious, often emotional instability and introversion), Openness (imagination, aesthetics, feelings, ideas, values, actions), Conscientiousness (competence, order, responsibility, achievement quest, internal discipline, prudence), Agreeableness (benevolence, forgiveness, kind, tolerant, respectful and flexibility) $[6,4,7,8]$.

One of the concepts that are associated with the personality is the "humor" concept. The humor often consists in the relationships between people, is also seen as a personality trait. [9]. According to Akdur (2014) the human as a social being frequently benefits from humor to communicate with other individuals but the styles of their 
humor differ from their personality traits[10]. In the simplest sense of humor is an element of comedy as wit, fun, teasing, satire and irony [11]. Martin and his friends (2003) define as fun, laughter, playfulness and similar behaviors, experiences, attitudes and individual differences of skills to this feeling handled in different forms [12].

Researchers who related humor have pointed to the difficulty of giving a definition accepted by everyone sense of humor. According to Martin (2004) this situation is connected with being quite a complex phenomenon in terms of sensory, behavioral, physical and social [11, 13].When It has been examined the literature related this area, It is appeared that individuals who have high levels of neurotic use self-devastating humor, individuals who have high levels of extroversion and openness use Affiliative humor and individuals who have low levels of docility and self-control use aggressive humor $[14,12]$. In the researches Humor is in the direction of that they have the ability to review and understanding that can be effective about activating to student, making the learning process enjoyable, reducing stress and tension, strengthening social relationships $[15,16,17,18]$. According to Kara (2014) when individual uses the humor with the positive purposes intended for itself or others it provides to the personality contributions such as positive relationship, self-enhancing, dealing with the challenges and the level of subjective well-being [9]. However, Humor always may not result with laughing action; it is content and result can bring about the devastating and aggression. In this context, It has been needed the forms of reflection, perception, interpretation and evaluation of the personality and humor in the point starting, developing and sustaining of the relationships among individuals because the ascriptions related individual's personality and humor is important in terms of determining how to act in their relationships. In these studies, It is suggested that contribute to the academic and sportive performance values of the responds of the questions such which humor methods used properly for the physical education and sports students' personalities, they have a trouble as which humor methods apply, which humor method the students enjoy to use. In this context, the purpose of the study is to analyze the skills of physical education and sports students' five factor personality perceptions and humor styles.

The relations between humor and personality have been analyzed by various authors, including Eysenck, Cattell, McGee and Ruch. However, the perspective of Martin et al. (2003) can be considered the most influential in current self-evaluative research. In constructing their Humor Styles Questionnaire (HSQ), these authors observed that humor styles had been considered in psychology for some time, and that they involved both positive and negative psychological functioning. They distinguished different types of humor that could be analyzed through an instrument that was better - compared to its predecessors for measuring the relations between mental health, emotions and humor.

According to cited by Mendiburo-Seguel et al. (2015); "The relations between humor and personality have been analyzed by various authors, including Eysenck, Cattell, McGee and Ruch. However, the perspective of Martin et al. (2003) can be considered the most influential in current self-evaluative research. In constructing their Humor Styles Questionnaire (HSQ), these authors observed that humor styles had been considered in psychology for some time, and that they involved both positive and negative psychological functioning. They distinguished different types of humor that could be analyzed through an instrument that was better - compared to its predecessors for measuring the relations between mental health, emotions and humor." Other studies in the literature have examined this relationship with different sample groups and different variables. Gender and age are influential on the personality and humor styles of the participants $[32,33$, 34]. However, this effect has been shown to a limited extent in how effective it is on physical education and sports college students. This study is important from the point of view of this relationship between university students.

It has been sought answers to the following hypothesis for this purpose:

H1: Is there a statistically meaningful relationship between score distributions of personality and humor style according to gender variable of the physical education and sports students?

$\mathrm{H} 2$ : Is there a statistically meaningful relationship between score distributions of personality and humor style according to age ranges of the physical education and sports students?

H3: Is there a statistically meaningful relationship between score distributions of personality and humor style according to class variable of the physical education and sports students?

\section{Material and Method}

In this part It is discussed the personal traits of the participants, the variables in the study, the properties of scales used to measure these variables and how they are applied (operation).

\section{Model of Research}

The study has been carried out on the basis of quantitative research design. The study is suitable for the relational scanning model that is one of the general scanning models for defining to determine the relationship between research variables, which is the general scanning model is made to scan on the universe of all or a sample taken from it to reach a general judgment about universe at 
a stage consisting of a plurality of elements [19].

\section{Participants}

The sample of the study has been consisted of students of Aydın Adnan Menderes University Physical Education and Sports College, Bartin University Physical Education and Sports College, Kutahya Dumlupinar Physical Education and Sports College, Manisa Celal Bayar University Sports Science Faculty. The distributions by various variables of the students consisting of the sample are given in Table 1.

It is seen that 487 of students are male $(\% 66,5), 403$ of them are in the age range $23-25(\% 55,1)$ and $(\% 38,9) 285$ of them are in the first class When looked to Table 1.

Table 1. The Percentage and frequency values of students' personal information

\begin{tabular}{|c|c|c|c|}
\hline \multirow{2}{*}{ Variables } & $F$ & $\%$ \\
\hline \multirow{4}{*}{ Gender } & Female & 245 & 33,5 \\
\cline { 2 - 4 } & Male & 487 & 66,5 \\
\cline { 2 - 4 } & Total & 732 & 100 \\
\hline \multirow{4}{*}{ Age } & 22 and below & 403 & 55,1 \\
\cline { 2 - 4 } & 23 and above & 329 & 44,9 \\
\cline { 2 - 4 } & Total & 732 & 100 \\
\hline \multirow{4}{*}{ Class } & 1 & 285 & 38,9 \\
\cline { 2 - 4 } & 2 & 167 & 22,8 \\
\cline { 2 - 4 } & 3 & 147 & 20,1 \\
\cline { 2 - 4 } & 4 & 133 & 18,2 \\
\cline { 2 - 4 } & Total & 732 & 100,0 \\
\hline
\end{tabular}

\section{Data Collection Tools}

"The five factor personality traits" and "Humor style scale" have been used as the data collection tools to determine whether the personality and humor styles of college students differ according to gender, age, class variables.

\section{The Five Factor Personality Traits Scale}

Table 2. Subdimensions of the Five Factor Personality Traits Scale

\begin{tabular}{|c|c|}
\hline Subdimensions & Items \\
\hline Neuroticism Factor & $4.9^{*} .14 .19 .24^{*} .29 .39$ \\
\hline Extraversion Factor & $1.6^{*} .11 .16 .21^{*} .31^{*} .36$ \\
\hline Openness Factor & $5.10 .15 .20 .25 .30 .35^{*} .40 .41^{*} .44$ \\
\hline Agreeableness Factor & $2^{*} .7 .12^{*} .17 .22 .27^{*} .32 .37^{*} .42$ \\
\hline Conscientiousness Factor & $3.8^{*} .13 .18^{*} .23 * .28 .33 .38 .43$ \\
\hline
\end{tabular}

(the items marked with * are evaluated as the opposite.)

The scale was developed by Benet-Martinez and John (1998) to measure personality traits) [35]. FFPTS is a self-report style, a 5-point Likert type (1-Never,
5-Completely), a 44-item measurement tool. The scale consists of five factors, outwardness, emotional imbalance (neuroticism), softness, responsibility and empathy. The Turkish 'to adapt the scale of a study on personality traits of participants of 56 countries (Schmitt, Blush, McCrae et al., 2007) [20] under the Turkey section, Sumer et al. (2005) is made and reliability coefficients for the subscales reported in range from 0.67 to 0.83 ) [36].

\section{Humor Styles (Humor Styles Questionnaire)}

Humor Styles Questionnaire - HSQ (Martin et al., 2003). This instrument has 32 items, measuring four styles of sense of humor (using 8 items for each of the styles). These styles are affiliative, self-enhancing, aggressive and self-defeating. Partici pants indicate their degree of agreement or disagreement with different statements about their sense of humor on a seven-point Likert-type scale, from 1 (totally disagree) to 7 (totally agree). Reliability of the scales for the original sample are 0.80 (af filiative), 0.81 (self-enhancing), 0.77 (aggressive) and 0.80 (self-defeating) [12]. The Scale's Turkish version has been made by Yerlikaya (2003) [21].

\section{Analysis of Data}

The data acquired as the result of the verse form and surveys has been benefited from parametric statistical analysis to compare with average, standard deviation, percentage, frequency distribution and some propositions by being used SPSS 22.0 statistical software. It has been analyzed with Shapiro-Wilk test whether the data shows normally distribution, It just has been understood that the subdimension of the openness does not carry the values of distribution $(p<0,05)$. When the kurtosis and skewness coefficients of this subdimension is analyzed, It has been understood that the coefficients of skewness is high $(-, 468)$.According to Karaatl $(2010)$ when the kurtosis and skewness coefficients of the subdimensions change , he has explained this subdimensions have the appropriate conditions, and This has been thought to be normally distribution in the subdimension because a significant deviation has been not observed in the plotted histogram [22]. In the study, the data having two variables such as gender and age have been analyzed by Independent Sample t-test and Class variable has been analyzed by One-Way ANOVA test. Besides, it has been benefited from Pearson correlation analysis to establish the relation between personality and humor styles of participants.

\section{Results}

It has not been found significant differences in sub-dimensions when analyses the sub-dimensions of humor style and personality according to the gender of the participants. 
1814 The Relationship between Humor Styles and Five Factor Personality Traits of Physical Education and Sports Students

Table 3. Comparison according to gender of personality and humor styles of the participants

\begin{tabular}{|c|c|c|c|c|c|c|}
\hline Subdimensions & Gender & $\mathrm{N}$ & $\bar{X}$ & SS & $\mathrm{t}$ & $\mathrm{P}$ \\
\hline \multirow{2}{*}{ Openness } & Male & 487 & 2,8193 & ,46609 & \multirow{2}{*}{, 355} & \multirow{2}{*}{723} \\
\hline & Female & 245 & 2,8063 & ,46724 & & \\
\hline \multirow{2}{*}{ Conscientiousness } & Male & 487 & 2,9003 &, 50473 & \multirow{2}{*}{,- 353} & \multirow{2}{*}{724} \\
\hline & Female & 245 & 2,9143 & ,51090 & & \\
\hline \multirow{2}{*}{ Extraversion } & Male & 487 & 2,9288 & 67133 & \multirow{2}{*}{,- 125} & \multirow{2}{*}{901} \\
\hline & Female & 245 & 2,9354 & 67483 & & \\
\hline \multirow{2}{*}{ Agreeableness } & Male & 487 & 2,8627 &, 52141 & \multirow{2}{*}{,- 912} & \multirow{2}{*}{362} \\
\hline & Female & 245 & 2,9015 & ,58205 & & \\
\hline \multirow{2}{*}{ Neuroticism } & Male & 487 & 2,8516 &, 52422 & \multirow{2}{*}{,- 094} & \multirow{2}{*}{925} \\
\hline & Female & 245 & 2,8554 &, 51581 & & \\
\hline \multirow{2}{*}{ Affiliative Humor } & Male & 487 & 3,1211 &, 55869 & \multirow{2}{*}{,- 455} & \multirow{2}{*}{649} \\
\hline & Female & 245 & 3,1413 & ,57970 & & \\
\hline \multirow{2}{*}{ Aggresive Humor } & Male & 487 & 3,2102 & ,44102 & \multirow{2}{*}{1,560} & \multirow{2}{*}{119} \\
\hline & Female & 245 & 3,1561 & ,44597 & & \\
\hline \multirow{2}{*}{ Self-devastating $\mathrm{H}$. } & Male & 487 & 3,0154 & ,65077 & \multirow{2}{*}{$-1,694$} & \multirow{2}{*}{091} \\
\hline & Female & 245 & 3,0995 &, 59851 & & \\
\hline \multirow{2}{*}{ Self-enhancing Humor } & Male & 487 & 3,1417 &, 46170 & \multirow{2}{*}{,277 } & \multirow{2}{*}{782} \\
\hline & Female & 245 & 3,1316 & 46691 & & \\
\hline
\end{tabular}

Table 4. Comparison according to gender range of personality and humor styles of the participants

\begin{tabular}{|c|c|c|c|c|c|c|}
\hline Subdimensions & Gender & $\mathrm{N}$ & $\bar{X}$ & SS & $\mathrm{t}$ & $\mathrm{P}$ \\
\hline \multirow{2}{*}{ Openness } & 22 and below & 403 & 2,8288 & ,47948 & \multirow{2}{*}{1,142} & \multirow{2}{*}{,238 } \\
\hline & 23 and above & 329 & 2,6329 & ,42657 & & \\
\hline \multirow{2}{*}{ Conscientiousness } & 22 and below & 403 & 2,8965 &, 51952 & \multirow{2}{*}{,- 288} & \multirow{2}{*}{,642 } \\
\hline & 23 and above & 329 & 2,9187 & ,50431 & & \\
\hline \multirow{2}{*}{ Extraversion } & 22 and below & 403 & 2,9189 & 69977 & \multirow{2}{*}{,- 436} & \multirow{2}{*}{, 578} \\
\hline & 23 and above & 329 & 2,9618 & ,63957 & & \\
\hline \multirow{2}{*}{ Agreeableness } & 22 and below & 403 & 2,8412 &, 55218 & \multirow{2}{*}{$-1,983$} & \multirow{2}{*}{, 052} \\
\hline & 23 and above & 329 & 2,93612 & ,53198 & & \\
\hline \multirow{2}{*}{ Neuroticism } & 22 and below & 403 & 2,8054 &, 51945 & \multirow{2}{*}{$-2,542$} & \multirow{2}{*}{, $013 *$} \\
\hline & 23 and above & 329 & 2,9185 &, 52620 & & \\
\hline \multirow{2}{*}{ Affiliative Humor } & 22 and below & 403 & 3,1321 &, 55046 & \multirow{2}{*}{,- 024} & \multirow{2}{*}{,982 } \\
\hline & 23 and above & 329 & 3,1429 & ,60812 & & \\
\hline \multirow{2}{*}{ Aggresive Humor } & 22 and below & 403 & 3,1802 &, 43683 & \multirow{2}{*}{$-1,102$} & \multirow{2}{*}{, 346} \\
\hline & 23 and above & 329 & 3,2287 & ,45419 & & \\
\hline \multirow{2}{*}{ Self-devastating Humor } & 22 and below & 403 & 3,1256 &, 56928 & \multirow{2}{*}{4,192} & \multirow{2}{*}{, $000^{*}$} \\
\hline & 23 and above & 329 & 2,9397 &, 70812 & & \\
\hline \multirow{2}{*}{ Self-enhancing Humor } & 22 and below & 403 & 3,1421 & ,47845 & \multirow{2}{*}{,388 } & \multirow{2}{*}{,672 } \\
\hline & 23 and above & 329 & 3,1318 & ,45958 & & \\
\hline
\end{tabular}

Their humor and personality characteristics have been compared in terms of ages of the participants. According to this, the participants $(X=2,9185+/-, 52620)$ in the age range 23 and above have achieved significantly higher scores in comparison with the participants $(X=2,8054+/-51945)$ in the age range 22 and below in the subdimension of Neuroticism $(\mathrm{t}=-2,542 ; \mathrm{p}<0,05)$. The participants $(\mathrm{X}=3,1256+/-, 56928)$ in the age range 22 and below has achieved high scores $(\mathrm{t}=4,192 ; \mathrm{p}<0,05)$ about self-devastating humor which is one of subdimensions of humor in proportion to the participants $(X=2,9397+/-70812)$ in the age range 23 and above. It has not been founded any differences in other subdimensions. 
Table 5. Comparison according to class variable of personality and humor styles of the participants

\begin{tabular}{|c|c|c|c|c|c|c|c|}
\hline Subdimensions & Class & $\mathrm{N}$ & $\overline{\mathrm{X}}$ & SS & $\mathrm{F}$ & $\mathrm{P}$ & LSD Comp. \\
\hline \multirow{4}{*}{ Openness } & 1 & 285 & 2,7992 & ,43457 & \multirow{4}{*}{1,611} & \multirow{4}{*}{, 185 } & \\
\hline & 2 & 167 & 2,7678 & ,51453 & & & \\
\hline & 3 & 147 & 2,8730 & ,45553 & & & \\
\hline & 4 & 133 & 2,8438 & ,47635 & & & \\
\hline \multirow{4}{*}{ Conscientiousness } & 1 & 285 & 2,9268 & ,50757 & \multirow{4}{*}{, 350} & \multirow{4}{*}{,789 } & \\
\hline & 2 & 167 & 2,8802 & ,54889 & & & \\
\hline & 3 & 147 & 2,8902 & ,48056 & & & \\
\hline & 4 & 133 & 2,9055 & ,47960 & & & \\
\hline \multirow{4}{*}{ Extraversion } & 1 & 285 & $3,0497^{*}$ & 69537 & \multirow{4}{*}{5,539} & \multirow{4}{*}{, $001 *$} & \multirow{4}{*}{$1>3$} \\
\hline & 2 & 167 & 2,8952 &, 71522 & & & \\
\hline & 3 & 147 & $2,7971^{*}$ & ,58829 & & & \\
\hline & 4 & 133 & 2,8697 & ,61557 & & & \\
\hline \multirow{4}{*}{ Agreeableness } & 1 & 285 & 2,8812 & ,56230 & \multirow{4}{*}{, 340} & \multirow{4}{*}{, 796} & \\
\hline & 2 & 167 & 2,8494 &, 57062 & & & \\
\hline & 3 & 147 & 2,9077 & ,52177 & & & \\
\hline & 4 & 133 & 2,8614 & ,48571 & & & \\
\hline \multirow{4}{*}{ Neuroticism } & 1 & 285 & 2,8206 & ,50878 & \multirow{4}{*}{2,972} & \multirow{4}{*}{, $031^{*}$} & \multirow{4}{*}{$3>2$} \\
\hline & 2 & 167 & $2,7887^{*}$ & ,52661 & & & \\
\hline & 3 & 147 & $2,9252^{*}$ & ,53748 & & & \\
\hline & 4 & 133 & 2,9227 & ,51011 & & & \\
\hline \multirow{4}{*}{ Affiliative Humor } & 1 & 285 & 3,1175 & ,47760 & \multirow{4}{*}{1,144} & \multirow{4}{*}{, 330} & \\
\hline & 2 & 167 & 3,1662 & ,62717 & & & \\
\hline & 3 & 147 & 3,1658 & ,62417 & & & \\
\hline & 4 & 133 & 3,0602 & ,58844 & & & \\
\hline \multirow{4}{*}{ Aggressive Humor } & 1 & 285 & 3,2232 &, 42828 & \multirow{4}{*}{4,383} & \multirow{4}{*}{, $005^{*}$} & \multirow{4}{*}{$2>3$} \\
\hline & 2 & 167 & $3,2246^{*}$ & ,44174 & & & \\
\hline & 3 & 147 & 3,2075 & ,45951 & & & \\
\hline & 4 & 133 & $3,0677^{*}$ & ,44101 & & & \\
\hline \multirow{4}{*}{ Self-devastating Humor } & 1 & 285 & 3,0912 & ,56888 & \multirow{4}{*}{1,397} & \multirow{4}{*}{, 242} & \\
\hline & 2 & 167 & 2,9835 & ,62267 & & & \\
\hline & 3 & 147 & 3,0663 &, 73360 & & & \\
\hline & 4 & 133 & 2,9915 & ,66201 & & & \\
\hline & 1 & 285 & $3,1961^{*}$ & ,50623 & & & \\
\hline Cuf ol & 2 & 167 & 3,1070 & ,45367 & $2602+2$ & $015 *$ & \\
\hline Sent-ennancing numor & 3 & 147 & $3,0757^{*}$ &, 42062 & 2,093 &, $045^{\circ}$ & $1>3$ \\
\hline & 4 & 133 & 3,1231 & ,41113 & & & \\
\hline
\end{tabular}

It has been compared with the subdimensions of the personality and humor style of the participants according to participants' classes. According to this, the first class students $(X=3,1961+/-, 50623)$ in the subdimension of self-enhancing humor have achieved significantly high scores $(\mathrm{F}=2,693 ; \mathrm{p}<0,05)$ in comparison with the third class students $(X=3,0757+/-, 42062)$. The second class students $(X=3,2246+/-, 44174)$ in the subdimension of aggressive humor have achieved significantly high scores $(\mathrm{F}=4,383 ; \mathrm{p}<0,05)$ in comparison with the fourth class students $(X=3,0677+/-, 44101)$. The first class students $(X=3,0497+/-, 6953)$ in the subdimension of extroversion have achieved significantly high scores $(\mathrm{F}=5,539 ; \mathrm{p}<0,05)$ in comparison with the third class students $(\mathrm{X}=2,7971+/-, 5882)$.

The second class students $(\mathrm{X}=2,7887+/-, 5266)$ in the subdimension of neuroticism have achieved significantly high scores $(F=2,927 ; p<0,05)$ in comparison with the third class students $(X=2,9252+/-, 5374)$. 
Table 6. The analysis of correlation between the personality and humor style of the participants

\begin{tabular}{|c|c|c|c|c|c|}
\hline & & Affiliative & Aggressive & Self-devastating & Self-enhancing \\
\hline \multirow{3}{*}{ Openness } & Pearson Correlation &, $096^{* *}$ &,- 016 &, $095^{*}$ &, 040 \\
\hline & Sig. (2-tailed) & 009 & 657 & 010 & ,276 \\
\hline & $\mathrm{N}$ & 732 & 732 & 732 & 732 \\
\hline \multirow{3}{*}{ Conscientiousness } & Pearson Correlation &, $206^{* *}$ &,- 038 &, $089^{*}$ &,- 005 \\
\hline & Sig. (2-tailed) &, 000 & ,303 & ,017 & 897 \\
\hline & $\mathrm{N}$ & 732 & 732 & 732 & 732 \\
\hline \multirow{3}{*}{ Extraversion } & Pearson Correlation &, $133^{* *}$ &,$- 076^{*}$ &, $106^{* *}$ &, $082^{*}$ \\
\hline & Sig. (2-tailed) & 000 & ,039 & ,004 & ,026 \\
\hline & $\mathrm{N}$ & 732 & 732 & 732 & 732 \\
\hline \multirow{3}{*}{ Agreeableness } & Pearson Correlation &, $093^{*}$ &,$- 093^{*}$ &, 063 & 011 \\
\hline & Sig. (2-tailed) & 012 & 012 & ,088 & ,775 \\
\hline & $\mathrm{N}$ & 732 & 732 & 732 & 732 \\
\hline \multirow{3}{*}{ Neuroticism } & Pearson Correlation &, $131^{* *}$ &,$- 091^{*}$ &, 004 &, 058 \\
\hline & Sig. (2-tailed) &, 000 &, 014 & ,918 &, 115 \\
\hline & $\mathrm{N}$ & 732 & 732 & 732 & 732 \\
\hline
\end{tabular}

Table 6 shows the relation between the subdimensions of the participants' personality and humor. According to this, it is seen that the levels of $(r=0,096 ; p<0,05)$ Affiliative humor and Self-devastating humor increase as long as Openness increases $(r=0,095 ; \mathrm{p}<0,05)$. It is seen $(r=0,089 ; \mathrm{p}<0,05)$ that the levels of Affiliative humor $(\mathrm{r}=0,206 ; \mathrm{p}<0,05)$ and self-devastating humor increase as long as Conscientiousness increases when we evaluate in terms of Conscientiousness' subdimension. Another important finding is related to the subdimension of extraversion. According to this, It is seen that the levels of Affiliative humor $(\mathrm{r}=0,133 ; \mathrm{p}<0,05)$, self-devastating humor( $\mathrm{r}=0,106 ; \quad \mathrm{p}<0,05)$ and self-enhancing $(\mathrm{r}=0,082$; $\mathrm{p}<0,05)$ increase but the level of aggressive humor decreases as long as extraversion increases $(\mathrm{r}=-0,076$; $\mathrm{p}<0,05)$. It has been observed rises in Both Agreeableness subdimensions $(\mathrm{r}=0,093 ; \mathrm{p}<0,05)$ and Neuroticism subdimensions $(\mathrm{r}=0,131 ; \mathrm{p}<0,05)$ as long as the level of Affiliative humor increases. And also It has been seen decreases in both Agreeableness subdimensions ( $\mathrm{r}=-0,093$; $\mathrm{p}<0,05)$ and Neuroticism subdimensions $(\mathrm{r}=-0,091$; $\mathrm{p}<0,05$ ) as long as the level of Aggressive humor increases.

\section{Discussion and Result}

In the study the five factor personality traits and humor styles of physical education and sports department students has been compared and analyzed with different variable.

According to the first hypothesis of the study, It has been analyzed if the five factor personality trait and humor style is difference according to gender variable or not.

According to the data in table 2, It has not been founded a significant difference between averages of total score from the five factor personality traits and humor styles scale in terms of gender variable.

This situation does not reveal a significant difference in terms of students' self-perception, personality and humor perceptions and gender. It has been seen that there is no difference between gender in the studies supporting our findings $[17,23]$. However, the literature points out differences $[23,29,30,31]$ that some studies $[24,25,26$, $27,28]$ are in favor of women and some studies are in favor of men. These determinations suggest that there always can be differences on the humor-focused five factor personality behavior of students and using of humor can change depending on personality, cultural factors and situational circumstances.

When studies in the literature are examined, positive humor styles have a positive effect on variables such as well-being, hope and mental health of the individual; [37, $38,39]$ and negative humor styles seem to be related to negative variables such as anger control [40]. There are studies in which humor styles are influenced by individual personality traits $[41,42,43]$. The common point of these studies and of this study is that there is a direct relationship between personality traits and humor styles of individuals. Positive humor feelings generally affect positive personality traits, while negative humor feelings are also related to negative personality traits. Humor and personality should not be considered separately. This study is important in terms of revealing that this relationship exists between the high school students of physical education and sports that are doing sports in a period of their life.

In addition, our findings contribute to the broader literature on the relationship between humor styles, personality and well-being [43, 44, 45]. One's personality appears to function as a lens that colors the way people 
view themselves and social settings. The use of positive or negative forms of humor seems to follow from the valence of that general lens and thus contributes to a positive or negative sense of well-being [43] Individuals with high humor styles feel happier in daily life. Happy university students are a happy community that can be formed in the future. In this sense, knowing the gender, age group and class of humor among the university students can lead to a map of happiness. Happiness affects an individual's psychological state positively. The findings of the present research, however, raise the possibility that inducing people to engage in adaptive forms of humor can have positive psychological outcomes among university students.

Consequently, It has been determined there is a relation between the five factor personality traits and humor styles of students, and also It has been appeared significant differences on the five factor personality traits and humor styles of students according to gender and class variables.

The following proposals have been developed in line with the results based on the findings and the findings of the study.

1. It is seen that there is an interaction between the five factor personality and humor styles of students. In the next studies, studying on different group and subjects can be helpful about revealing the effect on academic and sportive performance of students.

2. This study has been studied with students who making just sport. Having carried out in the manner that new studies will involve all of students group can be useful to reveal the solution and the effect of different problems and different age groups on the education and training.

3. The education based on the five factors and humor can help their change and development and can contribute positively to students' life who make sports.

\section{REFERENCES}

[1] Özer, D. J., Benet-Martinez, V. (2006). "Personality and the prediction of consequential outcomes". Annu Rev Psychol. 57: 401-21.

[2] Sığrı, Ü, Gürbüz, S. (2011). Akademik Başarı ve Kişilik İlişkisi: Üniversite Öğrencileri Üzerinde Bir Araştırma. Savunma Bilimleri Dergisi, 10 (1), 30-48.

[3] Basım, H.N. Çetin F. Tabak, A. (2009). Beş Faktör Kişilik Özelliklerinin Kişilerarası Çatışma Çözme Yaklaşımlarıyla İlişkisi, Türk Psikoloji Dergisi, 24(63), 20-34.

[4] Doğan, T., (2014), Beş Faktör Kişilik Özellikleri ve Öznel İyi Oluş, Doğuş Üniversitesi Dergisi, 14(1), 56-64.

[5] Şahin, N.H. (2013). "Stres ve Stres Yönetimi”, Örgütsel Davranış (Ed.: Sığrı Ü. Gürbüz S.) Beta Yayınları, İstanbul, s.266.
[6] Bacanl1, H. İlhan, T. Aslan, S., (2009). Beş Faktör Kişilik KURAMINA Dayalı Bir Kişilik Ölçeğinin Geliştirilmesi: Sıfatlara Dayalı Kişilik Testi. Türk Eğitim Bilimleri Dergisi, 7(2),261-279.

[7] Erkuş, A. Tabak, A., (2009). Beş Faktör Kişilik Özelliklerinin Çalışanların Çatışma Yönetim Tarzlarına Etkisi: Savunma Sanayiinde Bir Araştırma, Atatürk Üniversitesi İktisadi ve İdari Bilimler Dergisi, 23(2): 213-242.

[8] Somer, O., Korkmaz, M., Tatar, A. (2002).Beş Faktör Kişilik envanterinin geliştirilmesi-I: Ölçek ve alt ölçeklerin oluşturulması. Türk Psikoloji Dergisi, 17 (40), 21-33.

[9] Kara, H. (2014).Yöneticilerin Mizah Tarzlarının Uygulamadaki Durumunun Kurumsal ve Uygulamalı Olarak Açıklanması, Tarih Okulu Dergisi (TOD) Mart, 7(XVII): 701-724.

[10] Akdur, S., (2014).Kişilik Belirtileri ve Psikolojik Belirtiler Arasındaki İlişkide Kişilerarası İlişki Tarzları ve Mizah Tarzının Aracı Rolü, Yüksek Lisans, Ankara Üniversitesi, Sosyal Bilimler Enstitüsü, Psikoloji(Uygulamalı/Klinik Psikoloji) Anabilim Dal, Ankara.

[11] Kazarian, Shahe S. Martin, R.A. (2004). Humorstyles, personality and well-being among Lebanese university students. Europan Journal of Personality, 18, 209-219.

[12] Martin, R. A., Puhlik-Doris, P., Larsen, G., Gray, J. Weir, K. (2003). Individual differences of uses of humor amd their relation to prychological well-being: Development of the humor styles questionnaire. Journal of Research in Personality, 37 (1), 48-75.

[13] Boz U. (2014). Toplumsal Eleştiri Yöntemi Olarak Mizah ve Türk Mizahı: Yeni Medyadan Bahattin Örneği. Akdeniz İletişim Dergisi (21) 144-159.

[14] Jovanovic, V.(2011). Do Humor styles matter in the personality between personality and sunjective well-being? Scandinavian Journal of Psychology 52, 502-507.

[15] Martin, R.A. (2007). The Psychology of humor: An integrative approach. San Diego, CA: Elsevier Academic Press.

[16] Özdemir, S. Sezgin, F. Kaya, Z. Recepoğlu, E. (2011) "İlköğretim Okulu Öğretmenlerinin Stresle Başa Çıkma Tarzları ile Kullandıkları Mizah Tarzları Arasındaki İlişki”, Kuram ve Uygulamada Eğitim Yönetimi, 17(3):405-428.

[17] Sayar, B.(2012). Üniversite Öğrencilerinin Mizah Tarzları İle Umutsuzluk ve Boyun Eğici Davranışları Arasındaki İlişkinin İncelenmesi, Yüksek Lisans, Sakarya üniversitesi Eğitim Bilimleri enstitüsü, Sakarya.

[18] Yılmaz, K. (2011). Okul Yöneticilerinin Mizah Tarzlarının Çeşitli Değişkenler Açısından İncelenmesi, İnönü Üniversitesi Eğitim Fakültesi Dergisi, 12(1): 31-34.

[19] Karasar N. (2012). Bilimsel Araştırma Yöntemi, 21.Bask1, Nobel Yayın Dağıtım, Ankara, s.79.

[20] Schmitt, D.P. Allik, J. McCrate, R.R. Benet-Martinez, V. (2007). The Geographic Distribution of Big Five Personality Traits: Patterns and Profiles of Human Self-description Across 56 Nations. Journal of Cross-Cultural Psychology. 38(2), 173-212. 
[21] Yerlikaya E. E. (2003), "Mizah tarzları ölçeği (Humor styles questionnaire) uyarlama çalışması", Yüksek Lisans Tezi, Çukurova Üniversitesi, Sosyal Bilimler Enstitüsü, Adana.

[22] Karaatlı M (2010). Verilerin düzenlenmesi ve gösterimi, Editör: Kalaycı, Ş. SPSS uygulamalı çok değişkenli istatistik teknikleri, Asil Yayın Dağıtımı Ltd. Şti Ankara, s. 2-47.

[23] Çimen, B. (2011). Devlet ve Özel Okullarda Görev Yapan Sınıf Öğretmenlerinin Öğretim Sürecinde Mizah Kullanma Yeterlilikleri, Yüksek Lisans Tezi, Akdeniz Üniversitesi, Sosyal Bilimler Enstitüsü, Antalya.

[24] Avcı N. (2012). Üniversite Öğrencilerinin Mizah Tarzlarının, Psikolojik Belirtiler ve Ölüm Kaygısı İle İlişkisi. Yüksek Lisans Tezi, Sakarya Üniversitesi, Sakarya.

[25] Cann A. Matson C. (2014). Sense of humor and social desirability: Understanding how humor styles are perceived. Personality and Individual Differences, 66, 176-180.

[26] Yerlikaya N. (2007). Üniversite Öğrencilerinin Mizah Tarzlarının, Psikolojik Belirtiler ve Ölüm Kaygısı ile İlişkisi. Yüksek Lisans Tezi, Çukurova Üniversitesi, Adana.

[27] Tatar, A.(2009). Beş Faktör Kişilik Modeline Dayalı Olarak Sporcu Kadın ve Erkelerin Kișilik Profillerinin Karşılaştırılması, Hacettepe Üniversitesi Spor Bilimleri Dergisi, 20(2), 70-79.

[28] Tatlılıoğl1, K., (2014). Üniversite Öğrencilerinin Beş Faktör Kişilik Kuramı'na Göre Kişilik Özellikleri Alt Boyutlarının Bazı Değişkenlere Göre İncelenmesi, Tarih Okulu Dergisi(TOD), Mart, 7(XVII): 939-971.

[29] Aliyev, P., (2008). Beş Faktör Kişilik Özellikler ve Cinsiyet Rollerinin Üniversite Alan Seçimi İle İlişkisinin İncelenmesi, Yüksek Lisans, İstanbul Üniversitesi Sosyal Bilimler Enstitüsü, İstanbul.

[30] Akkaya, M. (2011). Sınıf Öğretmenlerinin Sınıf Yönetme Becerileri İle Mizah Tarzları Arasındaki İlișkinin İncelenmesi, Sempozyum: 20. Ulusal Eğitim Bilimleri Kurultay1, Pegem, İstanbul.

[31] Eryılmaz, A., Ercan, L., (2011). Öznel İyi Oluşun Cinsiyet, Yaş Grupları ve Kişilik Özellikleri Açısından İncelenmesi, Türk Psikolojik Danışma ve Rehberlik Dergisi, 4 (36), 139-151.

[32] Greven, C., Chamorro-Premuzicb, T., Arteche, A. \& Furnham, A. (2008). A hierarchical integration of dispositional determinants ofgeneral health in students: The Big Five, trait emotional intelligenceand humour styles. Personality and Individual Differences, 44, 15621573.

[33] Paez, D., Mendiburo-Seguel, A. \& Mart inez-S anchez, F. (2013). Incremen-tal validity of alexithymia, emotional coping and humor style on sub-jective and psychological well-being. Journal of Happiness Studies, 14, 1621-1637.
[34] Ruch, W. \& Heintz, S. (2013). Humour styles, personality and psycho-logical well-being: What's humour got to do with it? European Jour-nal of Humour Research, 1,1-24.

[35] Benet-Martinez,V., John, O.P. (1998). Los cinco grandes across cultures and ethnic groups: Multitrait multimethod analysis of the big five in Spanish and English. Journal of Personality and Social Psychology, 75, 729-750.

[36] Sumer, N., Lajunen, T. ve Özkan, T. (2005). Big fi ve personality traits as the distal predictors of road accident involvement. G. Underwood, (Ed.), Traffi c and transport psychology içinde. Elsevier Ltd.

[37] Westerman, R., Spies, K., Stahl, G. \& Hesse, F. (1996). Relative effec-tiveness and validity of mood induction procedures. European Jour-nal of Social Psychology, 26, 557-80

[38] Peterson, C. \& Park, N. (2009). Classifying and measuring strengths ofcharacter. In S. J. Lopez \& C. R. Snyder (Eds.), Oxford handbook ofpositive psychology (2nd edn) (pp. 25-33). New York: OxfordUniversity Press.

[39] Jovanovic, V. (2011). Do humor styles matter in the relationship betweenpersonality and subjective well-being? Scandinavian Journal of Psy-chology, 52, 502-507

[40] Torres-Marín, J., Navarro-Carrillo, G., \& Carretero-Dios, H. (2018). Is the use of humor associated with anger management? The assessment of individual differences in humor styles in Spain. Personality and Individual Differences, 120, 193-201.

[41] Mendiburo - Seguel, A., Páez, D., \& Martínez - Sánchez, F. (2015). Humor styles and personality: A meta - analysis of the relation between humor styles and the Big Five personality traits. Scandinavian journal of psychology, 56(3), 335-340.

[42] Vernon, P. A., Martin, R. A., Schermer, J. A., \& Mackie, A. (2008). A behavioral genetic investigation of humor styles and their correlations with the Big-5 personality dimensions. Personality and Individual Differences, 44(5), 1116-1125.

[43] Ford, T. E., Lappi, S. K., \& Holden, C. J. (2016). Personality, humor styles and happiness: Happy people have positive humor styles. Europe's journal of psychology, 12(3), 320.

[44] Veselka, L., Schermer, J. A., Martin, R. A., Cherkas, L. F., Spector, T.D. \& Vernon, P. A. (2010). A behavioral genetic study of relation-ships between humor styles and the six HEXACO personality factors.Europe's Journal of Psychology, 3, 9-33.

[45] Zeigler-Hill V., Besser A. (2011). Humor style mediates the association between pathological narcissism and self-esteem. Personality and Individual Differences, 50, 1196-1201. 10.1016/j.paid.2011.02.006

[46] Dozois D. J. A., Martin R. A., Bieling P. J. (2009). Early maladaptive schemas and adaptive/maladaptive styles of humor. Cognitive Therapy and Research, 33, 10.1007/s10608-008-9223-9 